\title{
Aristotle’s Definition of Place and of Matter
}

\author{
Peter Drum \\ The Australian Catholic University, Fitzroy Victoria, Australia. \\ Email: peter.drum@acu.edu.au \\ Received July $2^{\text {nd }}$, 2011; revised July 19 $9^{\text {th }}$, 2011; accepted July 25 $5^{\text {th }}, 2011$.
}

\begin{abstract}
The accuracy of Aristotle's definition of place is defended in terms of his form-matter theory. This theory is in turn defended against the objectionable notion that it entails matter is ultimately characterless.
\end{abstract}

Keywords: Aristotle, Place, Matter, Metaphysics

\section{Problems with Place?}

Aristotle defines place as "the innermost motionless boundary of what contains”. (Aristotle, 1952, Bekker, p. 212a20) "So when what is in a thing which is moved, is moved and changes its place, as a boat on a river, what contains plays the part of a vessel rather than that of place. Place, on the other hand, is that which is motionless; so it is rather the whole river that is placing, because as a whole it is motionless.” (Aristotle, 1952, Bekker, p. 212a15-20) But, this is arguably not without its difficulties. For, it seems to entail that "[f]irst, a ferry plying between the two banks will not change its place (it is always between the same banks). Secondly, two ferries between the same banks will be in the same place as each other. Thirdly, if the tide stops, the nearest immobile surface (and hence the place) will suddenly switch from being that of the banks to being that of the water in contact with the boat." (Sorabji, 1988: pp. 187-188) However, Aristotle is evidently seeking to define the whatness of place, not the whereness of it. This is because "in the river" answers the question "in what place?", not the question of "where in that place?" So, the latter might well refer to coordinates, as in terms of the banks and the river bed. Furthermore, whether it is moving or not, water is the matter of the river; and according to Aristotle things are defined first and foremost not in terms their matter, but in terms of their form. Therefore, that the water is immobile does not mean that the boat can now be said to be simply "in the water", because "the innermost motionless boundary of what contains”, is a river.

\section{Problems with Prime Matter?}

So, water is the matter of the river, but what is the matter of the matter? For, Aristotle contends the basic elements - earth, air, fire, and water-are not irreducible, holding as he does a theory of prime matter. Yet, this is also not without its difficulties if-as it is not uncommonly accepted-this means that prime matter is featureless. Frank A. Lewis advances this interpretation: "[prime] matter is not itself a kind of stuff or a kind of structure, in addition to the standard stuffs and structures - fire, flesh, flesh-and-bones_-found among changeable objects. Rather, we can usefully think of matter, in the standard case, in terms of the property the standard stuffs or structures of the changeable world must have in order to count as mat- ter...what counts as prime matter is not any kind of stuff or structure at all-it has no features of its own, beyond that it is matter and, hence, that it is capable of receiving contraries in generation and destruction ..." (Lewis, 2008: p. 133) But, how can something be thought of at all, without its being considered to have some features of its own? For example, when we are thinking of the matter of vapors, drops, puddles, ponds-and rivers - we are thinking of water, which is a certain kind of liquid. Therefore, the idea of something completely characterless seems to be absurd.

\section{Aristotle and Prime Matter}

It is fortunate, then, that this account of prime matter turns out in fact to dubiously be Aristotle's. For, he says that the apparently simple bodies of which all things are made-Earth, Air, Fire, and Water-are in fact "not simple, but blended. The 'simple' bodies are indeed similar in nature to them, but not identical with them.” (Aristotle, 1952, Bekker, p. 330b23-25) And, in answer to the question of whether the matter of these elements - Earth, Air, Fire, and Water-is the same, Aristotle suggests that "[p]erhaps the solution is that their matter is in one sense the same, but in another sense different. For that which underlies them, whatever its nature may be qua underlying them, is the same: but its actual being is not the same." (Aristotle, 1952, Bekker, p. 319b [emphasis added]) That is, what this basic material is, "is [that which is] 'such-as-fire"” and [that which is] 'such-as-air'; and so on with the rest of them.” (Aristotle, 1952, Bekker, p. 330b24) Yet, it has "no separate existence, but is always bound up with a contrariety" -namely, it is as Earth, Air, Fire, or Water. (Aristotle, 1952, Bekker, p. 329a26) Hence, what he means is that the same basic material can present to us in different ways. For example, suppose that prime matter were bronze. Bronze, then, would be that which is such-as-earth, and such-as-air, and so-on. Hence, the basic material-bronze — would be that which, as it exists, does so in modified ways.

\section{Defining Prime Matter}

Aristotle says elsewhere that "my definition of matter is just this - the primary substratum of each thing, from which it comes to be without qualification, and which persists in the 
result.” (Aristotle, 1952, Bekker, p. 192a32-33) For, again, if the primary material were bronze, everything would basically be bronze. And, "matter comes to be and ceases to be in one sense, while in another it does not. As that which contains the privation, it ceases to be in its own nature, for what ceases to be-the privation - is contained within it. But as potentiality it does not cease to be in its own nature, but is necessarily outside the sphere of becoming and ceasing to be." (Aristotle, 1952, Bekker, p. 192a25-28) That is, as bronze in a certain way-for example, as earth-bronze can cease to be; but in itself in a world of bronze it cannot, because if it loses that modification, it will then just assume another.

\section{The Character of Prime Matter}

Therefore, it would appear to be wrong to attribute to Aristotle the doctrine that prime matter is featureless. For Aristotle, prime matter is the basic material of which everything is ultimately made, since it is the material constitution of Earth, Air, Fire, and Water-as in the supposed case of bronze. This is because unless we posit such a material, how could the elements "come-to-be reciprocally out of one another, i.e. contrar- ies out of contraries?” (Aristotle, 1952, Bekker, p. 319b) Now, Sheldon Cohen is a supporter the idea that prime matter must have a character; however, he then says that "[t]he common matter of the four elements is at various times hot, cold, dry, and moist; it is never characterless"; (Cohen, 1996: p. 59) as if hot, cold, dry, and moist constituted the features of prime matter. But, this surely cannot be right. For, according to Aristotle these are determinations of something; and it is something about which all we can say has the character of being unknown.

\section{References}

Aristotle (1952). On Generation and Corruption. In R. M. Hutchins (Ed.), H. H. Joachim (Translate), The Works of Aristotle Volume 1 (pp. 407-441). Chicago, IL: William Benton.

Aristotle (1952). Physics. In R. M. Hutchins (Ed.), R. P. Hardie, \& R. K. Gaye (Translate), The Works of Aristotle Volume 1 (pp. 257-355). Chicago, IL: William Benton.

Cohen, S. (1996). Aristotle on Nature and Incomplete Substance. Cambridge: Cambridge University Press.

Lewis, F. A. (2008). What's the matter with prime matter? Oxford Studies in Ancient Philosophy, 34, 123-146.

Sorabji, R. (1988). Matter, Space and Motion. London: Duckworth. 